\title{
Seasonal and Cropping Effects on Total and Fertilizer Nitrogen Use in June-bearing and Day- neutral Strawberries
}

\author{
Douglas D. Archbold ${ }^{1}$ and Charles T. MacKown ${ }^{2}$ \\ University of Kentucky, Lexington, KY 40546-0091 \\ Additional index words. Fragaria $\times$ ananassa, $15 N$, recovery, remobilization, cycling
}

\begin{abstract}
Total N and fertilizer N (FN) recovery and use by June-bearing 'Redchief' strawberry (Fragaria $\times$ ananassa Duch.) and day-neutral 'Tribute' grown in matted-row beds were studied over l-year periods. Fertilizer $\mathbf{N}$ was fieldapplied as ${ }^{15} \mathrm{NH}_{4}{ }^{15} \mathrm{NO}_{3}$ at planting in June or September, and all plants were harvested from bed sections in late autumn (November) and at the completion of the spring harvest (June). Distribution patterns of vegetative biomass were similar in both cultivars, with leaf tissue comprising the bulk of the vegetative dry weight per plant at both sampling dates. The fall and spring fruit crops each contributed $>40 \%$ of the total biomass per plant. Total $N$ accumulation from soil $N$ and FN increased as total biomass increased. Due in part to the additional biomass of the fall fruit crop, 'Tribute' recovered $38 \%$ more total $N$ per unit bed area than 'Redchief'. Over $30 \%$ of the fall $N$ total in 'Tribute' and the spring $N$ total in both cultivars was partitioned to the fruit. In both cultivars, greater recovery of FN applied in September that at planting time was observed by the postharvest sampling date. However, 'Tribute' recovered only $14.2 \%$ of the FN applied in September, much less than the amount recovered by 'Redchief' during the same interval, implying a diminished ability to absorb FN during fruiting. In all vegetative tissues, soluble reduced $\mathbf{N}$ (SRN) was consistently less than insoluble reduced $N$ (IRN) in November and June. Consistent seasonal trends in SRN and IRN values were not evident in any tissue except roots, where SRN content declined from November to June. Allocation of FN to the SRN and IRN pools was related to FN application date, cropping pattern, and total biomass of the component tissue. In both cultivars, the FN content was greater in the IRN than the SRN pool and leaf IRN was the single largest vegetative sink for FN. Fruit $N$ concentration was constant for most of the fall 'Tribute' harvest period and declined in both cultivars during spring harvest. The spring 'Tribute' fruit crop received more FN from the September than the planting application, while the fall crop exhibited the opposite pattern, suggesting the fruit crop receives more storage than newly absorbed FN. The accumulation of FN in the root SRN pool in November and its depletion through the spring harvest reveals that root SRN plays a significant role in the temporary seasonal storage and internal cycling of $\mathbf{N}$ remobilized during spring growth.
\end{abstract}

Absorption of $\mathrm{N}$ by strawberry depends on many factors including soil properties, application method, and root zone temperature (Clay et al., 1984; Ganmore-Neumann and Kafkafi, 1983). Total fertilizer $\mathrm{N}(\mathrm{FN})$ recovery in matted row culture is low following planting, but greater when applied to mature beds with developed root systems (Archbold and MacKown, 1988). Increasing FN application rates at planting increase total FN recovery, although percent recovery values are lower at higher rates. The proportion of FN partitioned to the spring fruit crop in matted row culture increases slightly when the FN is applied in September instead of 3 months earlier at planting. Thus, the partitioning pattern depends on the time of year the FN is absorbed. Weinbaum et al. (1980, 1984) found that less FN is partitioned to the current fruit crop in almond and apricot and more goes to the fruit crop in the subsequent year as FN application date is delayed.

Total tissue $\mathrm{N}$ content and concentration of June-bearing strawberry cultivars changeover a growing season, indirectly indicating shifting patterns of internal $\mathrm{N}$ cycling among competing sinks. Although $\mathrm{N}$ availability may influence foliar $\mathrm{N}$ levels (Breen and

Received for publication 24 Mar. 1994. Accepted for publication 12 Sept. 1994 The investigation reported in this paper (93-10-45) is in connection with a project of the Kentucky Agricultural Experiment Station and is published with the approval of the director. This work was supported in part by grants from the North American Strawberry Growers Association and the Tennessee Valley Authority. The cost of publishing this paper was defrayed in part by the payment of page charges. Under postal regulations, this paper therefore must be hereby marked advertisement solely to indicate this fact.

'Associate professor, Dept. of Horticulture and Landscape Architecture. 'Plant physiologist, U.S. Dept. of Agriculture-Agricultural Research Service, and adjunct professor, Dept. of Agronomy.
Martin, 198 1; Hunan and Kotze, 1990), high foliar N levels present in early spring decline markedly in June-bearing cultivars during harvest and in late fall (Hunan and Kotze, 1990; John et al., 1976; Kwong and Boynton, 1959; Long and Murneek, 1937). In late fall, the crown and roots accumulate significant amounts of N, possibly supplying a portion of the $\mathrm{N}$ partitioned to the spring fruit crop. Fruit harvest removes significant amounts of $\mathrm{N}$ in June-bearing matted-row and annual production systems (Albregts and Howard, 1980; Archbold and MacKown, 1988). Since annual production systems involve sustained cropping with continual $\mathrm{N}$ removal from the internal $\mathrm{N}$ cycle and replenishment from newly absorbed soil $\mathrm{N}$ likely, the plants may exhibit different partitioning patterns than cultivars cropped seasonally in the spring. Lower root $\mathrm{N}$ concentration occurs when a day-neutral cultivar is cropped into the fall (Gagnon et al., 1990).

Plant tissues contain two major pools of $\mathrm{N}$, soluble and insoluble reduced N (SRN and IRN) compounds (Millard, 1988; Titus and Kang, 1982). In methanol-chloroform extraction protocols, the SRN pool includes reduced $\mathrm{N}$ primarily in the form of amines and amides. The IRN pool includes more complex forms of $\mathrm{N}$ such as nucleic acids and proteins. Undoubtedly, the regulation of the size of these two pools and their availability to sinks differ. Nitrogen may be transported in soluble forms such as nitrate and amino acids, while the IRN pool is not mobile. Both $\mathrm{N}$ pools may contribute to $\mathrm{N}$ accumulation in vegetative and reproductive sinks. Mobilization of $\mathrm{N}$ compounds from the foliage to stems and roots during senescence and the onset of dormancy occurs seasonally in perennial crops (Millard and Thomson, 1989; Titus and Kang, 1982). Some foliar N remains in dead leaves and may be recycled back into the soil $\mathrm{N}$ pool. The bark, roots, and stems are 
primary sites of $\mathrm{N}$ storage; the latter two may be potentially significant in strawberry.

In woody perennial fruit species, storage $\mathrm{N}$ continually contributes to vegetative and reproductive growth over several years, implying an important dynamic role for storage $\mathrm{N}$ in the $\mathrm{N}$ balance sheet for the perennial crop (Deng et al., 1989; Sanchez et al., 1991; Weinbaum and Muraoka, 1986). Early season vegetative and reproductive growth depend on mobilization of storage $\mathrm{N}$, and only after active leaf and/or shoot growth decreases is newly absorbed $\mathrm{N}$ a significant contributor to tissue $\mathrm{N}$ pools. Although the size of a strawberry plant and a fruit tree differ markedly, relative pool sizes and $\mathrm{N}$ partitioning patterns may be similar. In both, the fruit and leaves constitute a significant $\mathrm{N}$ sink during the growing season, and the roots and stem or crown may accumulate $\mathrm{N}$ during late fall (Long and Murneek, 1937; Titus and Kang, 1982). The shifting patterns of $\mathrm{N}$ accumulation among vegetative tissues in both species maybe responses to similar environmental cues.

There is a paucity of data on seasonal $\mathrm{N}$ and $\mathrm{FN}$ use in strawberry. The objective of this work was to determine the seasonal partitioning pattern of applied FN among tissues and allocation between the SRN and IRN pools and compare a Junebearing cultivar to a day-neutral cultivar to assess how fruiting pattern affects seasonal $\mathrm{N}$ use.

\section{Materials and Methods}

Field plots for Expts. 1 and 2 were established in a randomized complete-block design at the Univ. of Kentucky South Farm, Lexington, on a Maury silt loam soil (fine, mixed, mesic, Typic Paleudalf). Plots were fumigated several weeks before planting with 98 methyl bromide : 2 chloropicrin at $393 \mathrm{~kg} \cdot \mathrm{ha}^{-1}$. In May 1986, June-bearing 'Redchief' plants were set for Expt. 1. In May 1987, 'Redchief' and day-neutral 'Tribute' plants were set for Expt. 2. Commercially produced dormant plants were set $0.6 \mathrm{~m}$ apart in rows spaced every $1.5 \mathrm{~m}$. Individual beds $3 \mathrm{~m}$ in length were established. Inflorescences were removed from 'Redchief' plants after planting and from 'Tribute' plants until mid-July. Runner plants were manually set through September during each planting year to achieve a uniform bed density. Excess runners were directed beyond a $0.3-\mathrm{m}$ bed width. In September, beds were narrowed to $0.3 \mathrm{~m}$.

An aqueous solution of ammonium nitrate was banded $6 \mathrm{~cm}$ offcenter in a single-row into each bed 1 month after planting (June) and again after bed narrowing in early September. The ammonium nitrate was applied at $22.5 \mathrm{~kg} \mathrm{~N} / \mathrm{ha}$ on both dates. Each bed of 'Redchief' in Expt. 1 and 'Tribute' in Expt. 2 received ${ }^{15} \mathrm{~N}$ enriched ammonium nitrate $\left(6\right.$ atom $\%{ }^{15} \mathrm{~N}$, uniformly labelled, Amersham Corp., Arlington Heights, Ill.) on the June or the September application date, while 'Redchief' in Expt. 2 received FN in June only. Each cultivar and time of ${ }^{15} \mathrm{~N}$ application combination was replicated five times.

Standard cultural practices including disease and pest control were followed. Rainfall was supplemented with overhead irrigation to apply a minimum of $2.5 \mathrm{~cm}$ of water per week.

Ripe fruit were harvested weekly starting in late August from 'Tribute' plants during the first growing season and every 3 to 5 days from both cultivars during the following spring harvest. All fruit, ripe and unripe, were collected on the final fall harvest date for 'Tribute'. All plants within a $0.5-\mathrm{m}$ section of bed were sampled for dry weight, total N, and FN analysis in late November and following the completion of the spring harvest in both experiments. Care was taken to ensure maximum recovery of the root biomass. All plants from each sampled section were counted, thoroughly rinsed under running tap water, separated into component tissues, and bulked by tissue type. All tissues were frozen, lyophilized, and weighed. Vegetative tissues were ground in a Wiley mill to pass a 40-mesh screen, then pulverized to a fine powder with a ball mill. Intact fruit were pulverized to a powdery texture except those set aside for analysis of achene and receptacle tissues. Those tissues were manually separated and subsequently pulverized.

The SRN and IRN pools were fractionated and assayed by a methanol-chloroform procedure as described by Pace et al. (1982). This procedure volatilizes nitrate in the SRN fraction before Kjeldahl digestion. Aliquots of the Kjeldahl digests (McKenzie and Wallace, 1953) were analyzed spectrophotometrically for total $\mathrm{N}$. For ${ }^{15} \mathrm{~N}$ determination, an acid trap diffusion technique (MacKown et al., 1987) was used to prepare the $\mathrm{N}$ in Kjeldahl digests for mass spectrometry (Volk and Jackson, 1979).

Based on component tissue dry weights, $\mathrm{N}$ contents, and atom $\%{ }^{15} \mathrm{~N}$ values, FN recovery values were calculated for each component tissue type and the entire section as described by Hauck and Bremner ( 1976). Mean values \pm SE of the mean of component tissue dry weights and total $\mathrm{N}$ and total $\mathrm{FN}$ contents are presented.

\section{Results and Discussion}

Cultivar and environmental factors may have significant effects on dry weight accumulation and partitioning in strawberry. Plant density did not change between November and the subsequent June in Expt. 1, although total vegetative biomass increased (Table 1). Plant density in Expt. 1 exceeded that of Expt. 2, but plant density of 'Redchief' and 'Tribute' in Expt. 2 increased from

Table 1. Biomass distribution in the June-bearing strawberry cultivar Redchief and the day-neutral cultivar Tribute, 1986-88.

\begin{tabular}{|c|c|c|c|c|c|c|c|}
\hline \multirow[b]{2}{*}{ Date } & \multirow[b]{2}{*}{ Plants $/ \mathrm{m}^{2}$} & \multicolumn{6}{|c|}{ Dry wt $(\mathrm{g})$ per plant } \\
\hline & & Crown & Leaf & Petiole & Root & Fruit & Total \\
\hline \multicolumn{8}{|c|}{ Expt. 1, 1986-87, Redchief } \\
\hline November 1986 & $120 \pm 9^{7}$ & $1.1 \pm 0.2$ & $3.9 \pm 0.3$ & $1.1 \pm 0.1$ & $1.1 \pm 0.3$ & --- & $7.3 \pm 0.5$ \\
\hline June 1987 & $120 \pm 8$ & $2.2 \pm 0.1$ & $3.7 \pm 0.2$ & $2.1 \pm 0.1$ & $1.9 \pm 0.2$ & $8.2 \pm 0.4$ & $18.6 \pm 1.0$ \\
\hline \multicolumn{8}{|c|}{ Expt. 2, 1987-88, Redchief } \\
\hline November 1987 & $54 \pm 3$ & $1.2 \pm 0.4$ & $2.0 \pm 0.3$ & $0.5 \pm 0.1$ & $2.8 \pm 0.2$ & $\ldots$ & $6.4 \pm 0.9$ \\
\hline June 1988 & $86 \pm 11$ & $3.0 \pm 0.3$ & $4.2 \pm 0.4$ & $1.9 \pm 0.1$ & $3.4 \pm 0.9$ & $15.8 \pm 3.4$ & $28.6 \pm 2.7$ \\
\hline \multicolumn{8}{|c|}{ Tribute } \\
\hline November 1987 & $81 \pm 10$ & $2.3 \pm 0.5$ & $2.8 \pm 0.5$ & $0.8 \pm 0.2$ & $3.1 \pm 0.5$ & $8.3 \pm 1.0$ & $17.3 \pm 2.4$ \\
\hline June 1988 & $99 \pm 12$ & $3.6 \pm 0.4$ & $4.9 \pm 0.8$ & $1.8 \pm 0.3$ & $3.3 \pm 0.5$ & $13.6 \pm 2.5$ & $27.3 \pm 4.2$ \\
\hline
\end{tabular}

${ }^{\overline{ }}$ Mean \pm SE, $\mathrm{n}=10$ for 'Redchief' in Expt. 1 and 'Tribute' in Expt. 2, and $\mathrm{n}=5$ for 'Redchief' in Expt. 2. 
November to June. Vegetative biomass distribution patterns of the day-neutral 'Tribute' paralleled those of the June-bearing 'Redchief'. Total vegetative dry weight per plant increased between November and the subsequent June in both experiments. In November, roots contributed less than one-third the biomass of leaves in Expt. 1 but a greater proportion of the total in Expt. 2. Leaves contributed a greater proportion of the total biomass than roots at the postharvest sampling date in both experiments. Long and Mumeek (1937) observed that root tissue of container-grown plants comprised an equal or greater proportion of the total biomass compared to foliar tissue in November, but contributed proportionally less after harvest. Olsen et al. (1985) found a 3- to 4-fold greater leaf than root biomass at late fall and postharvest sampling dates for strawberry cultured in a hill system. The spring fruit crop of 'Redchief' comprised $>40 \%$ of the total biomass per plant in Expt. 1 and 55\% in Expt. 2, while the 'Tribute' fruit crops in Expt. 2 comprised nearly $50 \%$ of the total biomass values. While these values are within previously reported ranges, others have reported that cultivar, cultural procedures, and year-to-year environmental variation can have significant effects on biomass accumulation and distribution patterns (Baumann et al., 1993; Popenoe and Swartz, 1985).

As reported by Long and Murneek (1937) and Peterson et al. (1986), greater biomass accumulation resulted in greater total $\mathrm{N}$ accumulation. In Expt. 1, 'Redchief' absorbed $50 \%$ more $\mathrm{N}$ by the spring harvest than in November (Archbold and MacKown, 1988). In Expt. 2, 'Redchief' plants acquired nearly 4-fold more $\mathrm{N}$ by the spring harvest than in November (Table 2). Nearly half of the $\mathrm{N}$ was partitioned to the fruit. 'Tribute' accumulated $20.1 \mathrm{~g} \mathrm{~N} / \mathrm{m}^{2}$ by late November, >3-fold more $\mathrm{N}$ than 'Redchief'. Although this was due in part to the greater plant density and resulting vegetative biomass per unit bed area of 'Tribute', $6.9 \mathrm{~g} \mathrm{~N} / \mathrm{m}^{2}(33 \%)$ of the November $\mathrm{N}$ total was partitioned to the fruit. By the end of the spring harvest, 'Tribute' absorbed an additional $5.8 \mathrm{~g} \mathrm{~N} / \mathrm{m}^{2}$. The spring fruit crop contained $>30 \%$ of the total $\mathrm{N}$ absorbed. Although total $\mathrm{N}$ accumulation was similar by the two cultivars in June, the

Table 2. Total $\mathrm{N}$ absorbed and percent of applied fertilizer $\mathrm{N}$ recovered by the June-bearing cultivar Redchief and the day-neutral cultivar Tribute, Expt. $2, \quad 1987-88$

\begin{tabular}{|c|c|c|c|c|c|}
\hline \multirow{2}{*}{$\begin{array}{l}\mathrm{N} \text { application } \\
\text { date }\end{array}$} & \multirow{2}{*}{$\begin{array}{c}\text { Sampling } \\
\text { date }\end{array}$} & \multicolumn{2}{|c|}{ Total $\mathrm{N}$ absorbed $\left(\mathrm{g} \cdot \mathrm{m}^{-2}\right)$} & \multicolumn{2}{|c|}{ Recovery of fertilizer $\mathrm{N}(\%)$} \\
\hline & & Vegetative & Fruit & Vegetative & Fruit \\
\hline \multicolumn{6}{|c|}{ Redchief } \\
\hline June 1987 & November 1987 & $6.2 \pm 0.9^{7}$ & --- & $8.3 \pm 1.2$ & --- \\
\hline June 1987 & June 1988 & $13.2 \pm 2.4$ & $10.6 \pm 2.1$ & $11.0 \pm 4.2$ & $10.8 \pm 2.2$ \\
\hline \multicolumn{6}{|c|}{ Tribute } \\
\hline June 1987 & November 1987 & $13.2 \pm 1.8^{y}$ & $6.9 \pm 1.4$ & $13.8 \pm 1.1$ & $8.1 \pm 2.1$ \\
\hline June 1987 & June 1988 & $15.8 \pm 1.1$ & $10.1 \pm 0.7$ & $9.7 \pm 0.9$ & $4.7 \pm 1.3$ \\
\hline September 1987 & November 1987 & --- & --- & $11.8 \pm 4.6$ & $2.4 \pm 0.4$ \\
\hline September 1987 & June 1988 & --- & --- & $25.2 \pm 6.8$ & $8.1 \pm 3.6$ \\
\hline
\end{tabular}

${ }^{2}$ Mean \pm SE. For total $\mathrm{N}$ absorbed, $\mathrm{n}=5$ for 'Redchief' and $\mathrm{n}=10$ for 'Tribute'; for percent recovery, $\mathrm{n}=5$ for both cultivars.

${ }^{y}$ Means for total $\mathrm{N}$ absorbed across all plots at sampling date irrespective of fertilizer nitrogen application date.

Table 3. Soluble and insoluble N levels in Redchief and Tribute strawberry plant components, 1986-88.

\begin{tabular}{|c|c|c|c|c|c|}
\hline \multirow{2}{*}{ Tissue } & & \multicolumn{4}{|c|}{ Sampling date } \\
\hline & & \multicolumn{4}{|c|}{ Total $N$ content $(\mu \mathrm{mol} / \mathrm{plant})^{2}$} \\
\hline \multicolumn{6}{|c|}{ Expt. 1, 1986-87, Redchief } \\
\hline Crown & & $663 \pm 130^{y}$ & $1280 \pm 316$ & $365 \pm 30$ & $1160 \pm 39$ \\
\hline Leaf & - & $526 \pm 193$ & $5560 \pm 875$ & $200 \pm 13$ & $4430 \pm 287$ \\
\hline Root & & $948 \pm 64$ & $1150 \pm 94$ & $83 \pm 28$ & $931 \pm 126$ \\
\hline Fruit & & --- & --- & $1000 \pm 56$ & $4200 \pm 134$ \\
\hline \multicolumn{6}{|c|}{ Expt. 2, 1987-88, Redchief } \\
\hline Crown & & $634 \pm 225$ & $991 \pm 309$ & $935 \pm 162$ & $2080 \pm 267$ \\
\hline Leaf & & $189 \pm 22$ & $2620 \pm 318$ & $378 \pm 6$ & $4360 \pm 335$ \\
\hline Petiole & & $30 \pm 4$ & $243 \pm 16$ & $129 \pm 1$ & $746 \pm 79$ \\
\hline Leaf & & $213 \pm 26$ & $3860 \pm 716$ & $475 \pm 67$ & $5130 \pm 744$ \\
\hline Petiole & & $67 \pm 10$ & $455 \pm 83$ & $93 \pm 8$ & $672 \pm 94$ \\
\hline Root & & $1750 \pm 154$ & $2860 \pm 940$ & $218 \pm 93$ & $2550 \pm 691$ \\
\hline Fruit & & $2150 \pm 604$ & $3950 \pm 419$ & $2030 \pm 284$ & $10500 \pm 2110$ \\
\hline
\end{tabular}

${ }^{\overline{2}}$ To derive percent $\mathrm{N}$ values, divide the sum of the soluble and insoluble means by the dry weight (Table 1 ) and multiply by $1.4 \times 10^{-3}$

${ }^{y}$ Mean \pm SE. $n$ as in Table 1 . 
Table 4. Influence of fertilizer $\mathrm{N}$ application date on fertilizer $\mathrm{N}$ content of the soluble and insoluble $\mathrm{N}$ pools of 'Redchief' strawberry plant tissues in November 1986 and after harvest in June 1987, Expt. 1.

\begin{tabular}{|c|c|c|c|c|}
\hline \multirow[b]{4}{*}{ Tissue } & \multicolumn{4}{|c|}{$\mathrm{N}$ application date } \\
\hline & \multicolumn{2}{|c|}{ June 1986} & \multicolumn{2}{|c|}{ September 1986} \\
\hline & \multicolumn{4}{|c|}{ Total fertilizer $\mathrm{N}$ content $(\mathrm{nmol} / \mathrm{plant})$} \\
\hline & Soluble & Insoluble & Soluble & Insoluble \\
\hline \multicolumn{5}{|c|}{ November 1986} \\
\hline Crown & $713 \pm 34^{z}$ & $1230 \pm 143$ & $3870 \pm 672$ & $6850 \pm 1420$ \\
\hline Leaf & $862 \pm 77$ & $21400 \pm 1990$ & $2060 \pm 776$ & $27600 \pm 2910$ \\
\hline Petiole & $270 \pm 58$ & $1860 \pm 213$ & $152 \pm 70$ & $2710 \pm 538$ \\
\hline Root & $406 \pm 52$ & $715 \pm 97$ & $8220 \pm 1140$ & $8430 \pm 1220$ \\
\hline \multicolumn{5}{|c|}{ June 1987} \\
\hline Crown & $768 \pm 119$ & $3090 \pm 434$ & $1400 \pm 278$ & $4150 \pm 660$ \\
\hline Leaf & $327 \pm 79$ & $8610 \pm 2370$ & $598 \pm 17$ & $13800 \pm 748$ \\
\hline Petiole & $166 \pm 85$ & $2200 \pm 113$ & $133 \pm 58$ & $2470 \pm 84$ \\
\hline Root & $127 \pm 20$ & $3110 \pm 864$ & $364 \pm 213$ & $2970 \pm 553$ \\
\hline Fruit & $2410 \pm 304$ & $10600 \pm 1450$ & $3310 \pm 1020$ & $12900 \pm 3510$ \\
\hline
\end{tabular}

$\bar{M}$ Mean \pm SE, $\mathrm{n}=5$.

Table 5. Influence of fertilizer $\mathrm{N}$ application date on fertilizer $\mathrm{N}$ content of the soluble and insoluble nitrogen pools of 'Tribute' strawberry plant tissues in November 1987 and after harvest in June 1988, Expt.2.

\begin{tabular}{|c|c|c|c|c|}
\hline \multirow[b]{4}{*}{ Tissue } & \multicolumn{4}{|c|}{$\mathrm{N}$ application date } \\
\hline & \multicolumn{2}{|c|}{ June 1987} & \multicolumn{2}{|c|}{ September 1987} \\
\hline & \multicolumn{4}{|c|}{ Total fertilizer $\mathrm{N}$ content (nmol/plant) } \\
\hline & Soluble & Insoluble & Soluble & Insoluble \\
\hline \multicolumn{5}{|c|}{ November 1987} \\
\hline Crown & $3600 \pm 549^{z}$ & $7310 \pm 1410$ & $2970 \pm 873$ & $6090 \pm 2680$ \\
\hline Leaf & $811 \pm 147$ & $15500 \pm 1990$ & $458 \pm 158$ & $10300 \pm 5430$ \\
\hline Petiole & $269 \pm 40$ & $1870 \pm 182$ & $192 \pm 83$ & $1180 \pm 574$ \\
\hline Root & $4190 \pm 256$ & $6630 \pm 1011$ & $11700 \pm 4180$ & $17200 \pm 1190$ \\
\hline Fruit & $12100 \pm 1680$ & $200000 \pm 6310$ & $4260 \pm 559$ & $6400 \pm 262$ \\
\hline \multicolumn{5}{|c|}{ June 1988} \\
\hline Crown & $1950 \pm 234$ & $6770 \pm 991$ & $4570 \pm 2820$ & $13300 \pm 8110$ \\
\hline Leaf & $1030 \pm 173$ & $12700 \pm 2160$ & $2190 \pm 948$ & $25300 \pm 8270$ \\
\hline Petiole & $249 \pm 78$ & $1700 \pm 305$ & $524 \pm 213$ & $3820 \pm 1610$ \\
\hline Root & $752 \pm 509$ & $8600 \pm 4180$ & $790 \pm 651$ & $12000 \pm 197$ \\
\hline Fruit & $3500 \pm 334$ & $19400 \pm 1860$ & $6650 \pm 1040$ & $27000 \pm 4220$ \\
\hline
\end{tabular}

${ }^{\overline{2}}$ Mean $\pm \mathrm{SE}, \mathrm{n}=5$.

dual fall and spring fruiting pattern of 'Tribute' contributed to a greater total $\mathrm{N}$ accumulation than 'Redchief'. The fall fruit plus spring vegetative and fruit $\mathrm{N}$ total of $32.8 \mathrm{~g} \mathrm{~N} / \mathrm{m}^{2}$ accumulated by 'Tribute' was $38 \%$ more than the June-bearing 'Redchief' spring total of $23.8 \mathrm{~g} \mathrm{~N} / \mathrm{m}^{*}$. These results indicated a greater $\mathrm{N}$ requirement by dual-cropped day-neutral than June-bearing cultivars when grown in matted rows. In annual strawberry production in Florida, total plant and fruit crop accumulation is nearly $60 \mathrm{~kg} \mathrm{~N} /$ ha over several months (Albregts and Howard, 1980), while Junebearing cultivars grown in matted rows may accumulate up to 80 $\mathrm{kg} \mathrm{N} / \mathrm{ha}$ (Archbold and MacKown, 1988; Peterson et al., 1986).

Fruiting may alter $\mathrm{N}$ absorption patterns. More FN was absorbed by 'Tribute' than 'Redchief' by November from the planting application in Expt. 2, although total FN recovery by 'Redchief' was comparable to 'Tribute' by June (Table 2). In November, recovery of FN applied to 'Tribute' plants in September was less than that from the planting application. In contrast to 'Redchief' in Expt. 1 when $24 \%$ of the September-applied FN was recovered by November (Archbold and MacKown, 1988), 'Tribute' recovered only $14.2 \%$ of the September FN application by late fall, but had absorbed $33.3 \%$ by the spring harvest. Several factors may account for less FN recovery between September and November by 'Tribute' in Expt. 2 than 'Redchief' in Expt. 1. A shift in carbohydrate partitioning to the fruit crop could have reduced the carbohydrate supply to the roots, impairing energy-dependent nitrate absorption and limiting $\mathrm{N}$ assimilation. Root growth slows considerably during fruiting, implying a redirection of carbohydrate resources to other tissues (Olsen et al., 1985). In both experiments, 'Redchief' root biomass increased from November to June proportionally more than in 'Tribute', which produced fall fruit and may have partitioned less carbohydrate to roots. Strawberry utilizes nitrate more effectively than ammonium during flowering and fruiting, which could also influence recovery (Ganmore-Neumann and Kafkafi, 1985). Inherent cultivar variation and environmental effects on soil $\mathrm{N}$ conversion and recovery potential could have been factors also.

The total IRN content per plant exceeded that of SRN in vegetative tissues of both cultivars at both sampling dates, and leaf IRN content was the greatest single $\mathrm{N}$ pool (Table 3 ). Although Long and Murneek ( 1937) observed a seasonal decline in total N 

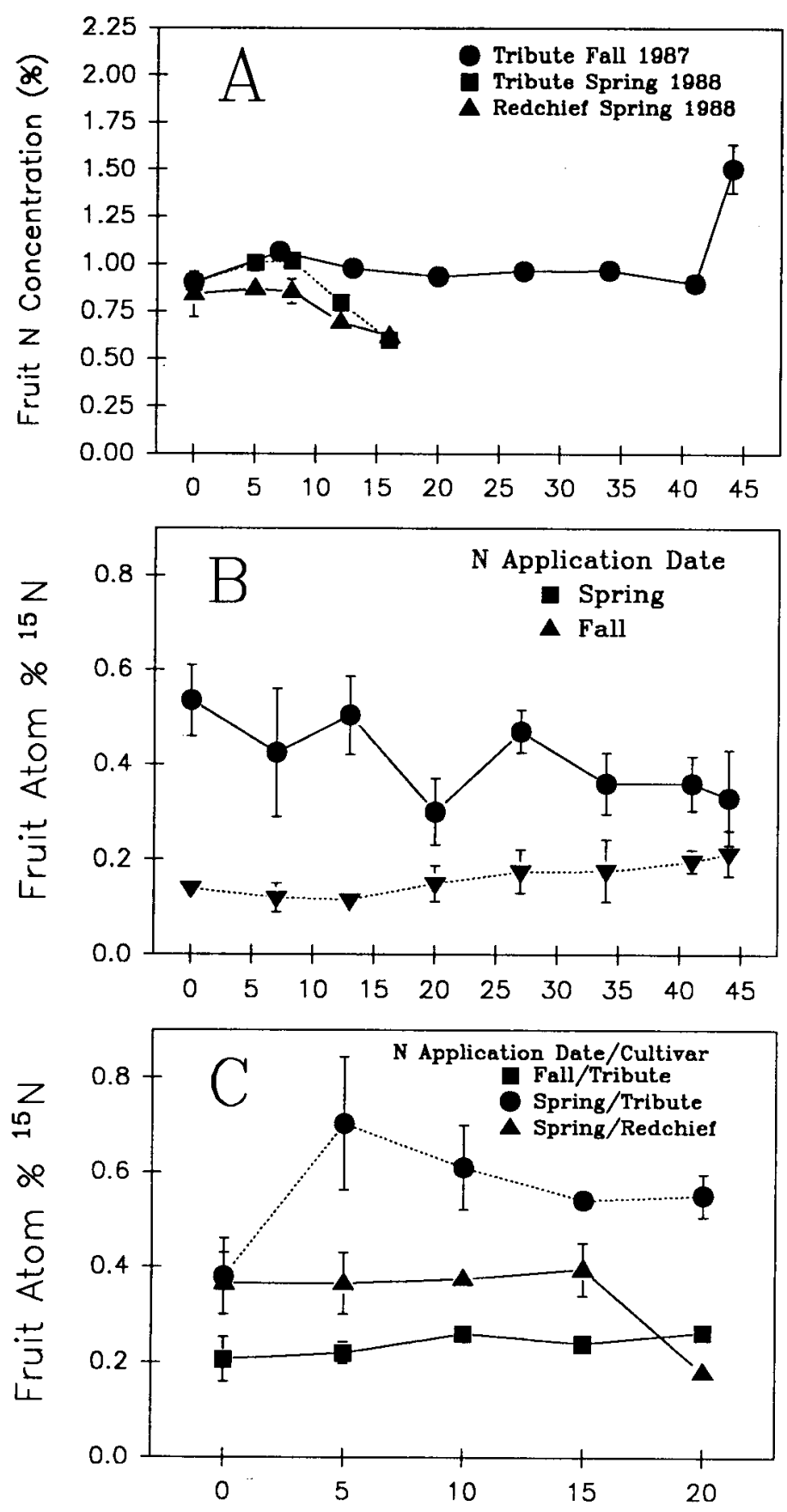

Days After First Harvest

Fig. 1. Fruit $\mathrm{N}$ concentration and enrichment with ${ }^{15} \mathrm{~N}$, Expt. 2, 1987-88. (A) Fruit $\mathrm{N}$ concentration at each harvest date in the fall 'Tribute' crop and the spring 'Tribute' and 'Redchief' crops, (B) Fruit $\mathrm{N}$ enrichment with ${ }^{15} \mathrm{~N}$ at each fall harvest date for 'Tribute', (C) Fruit $\mathrm{N}$ enrichment with ${ }^{15} \mathrm{~N}$ at each spring harvest date for 'Tribute' and 'Redchief. Each point is the mean of three replications. If the SE bar is not evident, the SE was smaller then the symbol.

content of most vegetative tissues, consistent seasonal differences in $\mathrm{N}$ content of the pools were not evident in any tissue except roots across cultivars or experiments in this study. Across experiments and cultivars, root SRN content declined $>80 \%$ from November to June, while root IRN content varied $<20 \%$. Root dry weight and total plant $\mathrm{N}$ increased in both cultivars, so more $\mathrm{N}$ was absorbed from November to June. The decline in root SRN content maybe an important physiological aspect of growth resumption and fruiting in the spring. Storage $\mathrm{N}$ reserves contribute significantly to early season vegetative and reproductive growth in herbaceous and woody species (Birkhold and Darnell, 1993; Cyr and Bewley, 1989; Deng et al., 1989; Millard and Thomson, 1989; Sanchez et al., 199 1), as well as to reproductive growth in herbaceous annual crops (Ta and Weiland, 1992; Van Sanford and MacKown, 1987). Root $\mathrm{N}$ as amino acids (Sagisaka, 1987) may provide a readily mobile storage reserve.

Partitioning of FN among vegetative tissues was a function of season of FN application, cropping pattern, and the total biomass of the individual tissue. Within component tissues, FN was allocated to the SRN and IRN pools (Tables 4 and 5). The leaf IRN pool was the single largest vegetative sink for FN in 'Redchief' (Table 4) as it was for total N. In November, the FN content of the IRN pool in all 'Redchief' tissues was greater than that in the SRN pool regardless of $\mathrm{N}$ application date. Both pools in all vegetative tissues exhibited a decline in FN content from November to June in plants receiving FN in September. However, the IRN pool of crown and root tissues of 'Redchief' plants receiving FN at planting exhibited increased FN content by June, a pattern repeated in Expt. 2 (data not shown). Continued absorption of FN from the soil and remobilization of FN from tissues exhibiting the November to June decline could account for this trend. New foliage produced in the spring probably plays a greater role as a $\mathrm{N}$ sink than a source, and the decline in foliar FN content likely reflects both remobilization and absorption during spring growth.

Regardless of FN application date, the FN content of the IRN pool in all 'Tribute' tissues was generally greater than the SRN pool on both sampling dates (Table 5). Although the foliar IRN pool was generally the largest vegetative sink for FN, root IRN in November contained more FN in plants receiving FN in September. However, as described previously for total FN recovery, the FN content of all tissues except the roots was less in November when FN was applied in September than at planting. In plants receiving FN in September, the pools inmost tissues except roots contained more FN in June than in November. The FN content of the root SRN pool declined from November to June for both application dates, similar to the decline observed in 'Redchief' root tissue.

During the fall 'Tribute' harvest, fruit $\mathrm{N}$ concentration generally did not vary (Fig. 1A). Fruit $\mathrm{N}$ concentration of both cultivars declined slightly as harvest progressed in the spring. Fruit exhibited high levels of both $\mathrm{N}$ pools compared to vegetative tissues and, as in vegetative tissue, the values of IRN were greater than the SRN values (Table 3). The June FN application enriched fall fruit $\mathrm{N}$ in 'Tribute' more than the September FN application in spite of the latter application during the fall cropping period (Fig. $1 \mathrm{~B}$ ). Thus, fruit development was a greater sink for storage FN acquired in the months before cropping than for newly absorbed N. During the subsequent spring harvest, the September FN application enriched fruit more than the planting FN application (Fig. 1C). 'Redchief' fruit tissue ${ }^{15} \mathrm{~N}$ enrichment from $\mathrm{FN}$ applied at planting was generally greater than that for 'Tribute' during the spring harvest. This implies the depletion of plant FN by the fall Tribute fruit crop, since both cultivars experienced the same seasonal environments influencing $\mathrm{N}$ availability in the soil profile. Achene tissue from 'Redchief' fruit had a greater $\mathrm{N}$ concentration than receptacle tissue, $2.4 \%$ vs. $0.7 \%$, respectively, but they had the same level of fertilizer $\mathrm{N}$ enrichment. Both tissues accumulated slightly more fall-applied than spring-applied FN, 0.38 vs. $0.26 \%$, respectively. A similar pattern of late season $\mathrm{N}$ application accumulation by fruit tissues the subsequent season has been observed in other fruit crops (Weinbaum et al., 1980). 
Some general trends were observed in this study. Total $\mathrm{N}$ and FN content were related to biomass production $(r=0.81, P<0.05)$. Thus, the $\mathrm{N}$ requirement of day-neutral varieties cropped over several months would be significantly greater than that of Junebearing varieties. From total recovery (Table 2) and per plant values (Tables 4 and 5), it was evident that FN recovery occurred over a long interval after FN application, indicating that FN remained available in the soil profile through the end of the experiments. Fruiting affected FN recovery during the fall cropping period as total recovery was very low in November but increased through June when 'Tribute' received FN in September. The reduced level of FN recovery by both cultivars after planting and by Tribute during fruiting suggested that application rates and timing should be tailored to the plants' needs and their ability to absorb N.

Internal $\mathrm{N}$ cycling, as described for other perennial crops (Deng et al., 1989; Millard and Neilsen, 1989; Sanchez et al., 1991; Titus and Kang, 1982), was evident, especially in strawberry roots. A consideration of $\mathrm{N}$ cycling including the nitrate pool would be valuable, although the nitrate pool may be small in comparison to the reduced $\mathrm{N}$ pools. The total $\mathrm{N}$ in the reduced $\mathrm{N}$ pools was $>90 \%$ of the total vegetative tissue $\mathrm{N}$ (data not shown). Fertilizer $\mathrm{N}$ distribution generally followed the patterns of total $\mathrm{N}$ partitioning among tissues and allocation between SRN and IRN pools. Although seasonal variation was evident, only total $\mathrm{N}$ and FN content of the root SRN pool consistently declined from November to June in both cultivars and experiments independent of FN application date. The SRN pool of root tissue may play a significant role in storage and internal cycling of $\mathrm{N}$, which may be remobilized to vegetative and reproductive growth in the spring. Both storage and newly absorbed $\mathrm{N}$ and FN may be partitioned to the fruit crop although storage reserves may contribute proportionally more during the cropping period.

\section{Literature Cited}

Albregts, E.E. and C.M. Howard, 1980. Accumulation of nutrients by strawberry plants and fruit grown in annual hill culture. J. Amer. Soc. Hort. Sci. 105:386-388.

Archbold, D.D. and C.T. MacKown. 1988. Fate of fertilizer nitrogen in matted-row strawberry culture. Adv. Strawberry Prod. 7:32-35.

Baumann, T. E., G.W. Eaton, and D. Spaner. 1993. Yield components of day-neutral and short-day strawberry varieties on raised beds in British Columbia. HortScience 28:891-894.

Birkhold, K.T. and R.L. Darnell. 1993. Contribution of storage and currently assimilated nitrogen to vegetative and reproductive growth in rabbiteye blueberry. J. Amer. Soc. Hort. Sci. 118:101-108.

Breen, P.J. and L.W. Martin. 1981. Vegetative and reproductive growth responses of three strawberry cultivars to nitrogen. J. Amer. Soc. Hort. Sci. 106:266-272.

Clay, D. E., R.L. Mahler, and H.A. Menser. 1984. The influence of N sources and rates on soil $\mathrm{N}$ parameters related to strawberry production in northern Idaho. Commun. Soil Sci. Plant Anal. 15:819-872.

Cyr, D.R. and J.D. Bewley. 1989. Carbon and nitrogen reserves of leafy spurge (Euphorbia esula) roots as related to overwintering strategy. Physiol. Plant. 77:67-72.

Deng, X., S.A. Weinbaum, T.M. DeJong, and T.T. Muraoka. 1989. Utilization of nitrogen from storage and current-year uptake in walnut spurs during the spring flush of growth. Physiol. Plant. 75:492-498.

Gagnon, B., Y. Desjardins, and R. Bedard. 1990. Fruiting as a factor in accumulation of carbohydrates and nitrogen and in fall cold hardening of day-neutral strawberry roots. J. Amer. Soc. Hort. Sci. 115:520-525. Ganmore-Neumann, R. and U. Kafkafi. 1983. The effect of root temperature and $\mathrm{NO}_{3}^{-} / \mathrm{NH}_{4}^{+}$ratio on strawberry plants. I. Growth, flowering, and root development. Agron. J. 75:94 1-947.
Ganmore-Neumann, R. and U. Kafkafi. 1985. The effect of root temperature and nitrate/ammonium ratio on strawberry plants. II. Nitrogen uptake, mineral ions, and carboxylate concentrations. Agron. J. 77:835840 .

Hauck, R.D. and J.M. Bremner. 1976. Uses of tracers for soil and fertilizer nitrogen research. Adv. Agron. 28:219-266.

Hunan, C. and W.A.G. Kotze. 1990. Effect of nitrogen and potassium fertilization on strawberries in an annual hill culture system. 111. Leaf nutrient levels. Commun. Soil Sci. Plant Anal. 21:795-810.

John, M. K., H.A. Daubeny, and F.D, McElroy. 1976. Influence of sampling time on elemental composition of strawberry leaves and petioles. J. Amer. Soc. Hort. Sci. 100:513-517.

Kwong, S.S. and D. Boyntom 1959. Time of sampling, leaf age, and leaf fraction as factors influencing the concentrations of nutrient elements in strawberry leaves. Proc. Amer. Soc. Hort. Sci. 77: 168-173.

Long, J.H. and A.E. Mumeek. 1937. Nitrogen and carbohydrate content of the strawberry plant. Seasonal changes and effects of fertilizers. Missouri Agr. Expt. Sta. Bul. 252.

MacKown, C. T., P.D. Brooks, and M.S. Smith. 1987. Diffusion of nitrogen- 15 Kjeldahl digests for isotope analysis. Soil Sci. Soc. Amer. J. 51:87-90.

McKenzie, H. and H.S. Wallace. 1953. The Kjeldahl determination of nitrogen: A critical study of digestion conditions-Temperature, catalyst, and oxidizing agent. Austral. J. Chem. 7:55-70.

Millard, P. 1988. The accumulation and storage of nitrogen by herbaceous plants. Plant Cell Environ. 11:1-8.

Millard, P. and G.H. Neilsen. 1989. The influence of nitrogen supply on the uptake and remobilization of stored $\mathrm{N}$ for the seasonal growth of apple trees. Ann. Bet. 63:301-309.

Millard, P. and C.M. Thomson. 1989. The effect of the autumn senescence of leaves on the internal cycling of nitrogen for the spring growth of apple trees. J. Expt. Bet. 40: 1285-1289.

Olsen, J. L., L.W. Martin, P.J. Pelofske, P.J. Breen, and C.F. Forney. 1985. Functional growth analysis of field-grown strawberry. J. Amer. Sot. Hort. Sci. 110:89-93.

Pace, GM., C.T. MacKown, and R.J. Volk. 1982. Minimizing nitrate reduction during Kjeldahl digestion of plant tissue extracts and stem exudates. Plant Physiol. 69:32-36.

Peterson, L. A., E.J. Stang, and A. Krueger. 1986. Growth and nutrient uptake of strawberry during first-year development in a matted-row cultural system. Adv. Strawberry Prod. 5: 11-17.

Popenoe, J. and. H.J. Swartz. 1985. Yield component comparison of strawberry plants grown in various cultural systems. Adv. Strawberry Prod. 4:10-14.

Sagisaka, S. 1987. Amino acid pools in herbaceous plants at the wintering stage and at the beginning of growth. Plant Cell Physiol. 28:171-178.

Sanchez, F. F., T.L. Righetti, D. Sugar, and P.B. Lombard. 1991. Recycling of nitrogen in field-grown 'Cornice' pears. J. Hort. Sci. 66:479486.

Ta, C.T. and R.T. Weiland. 1992. Nitrogen partitioning in maize during ear development. Crop. Sci. 32:447451.

Titus, J.S. and S. Kang. 1982. Nitrogen metabolism, translocation, and recycling in apple trees. Hort. Rev. 4:204-246.

Van Sanford, D.A. and C.T. MacKown. 1987. Cultivar differences in nitrogen remobilization during grain fill in soft red winter wheat. Crop Sci. 27:291-300.

Volk, R.J. and W.A. Jackson. 1979. Preparing nitrogen gas for nitrogen15 analysis. Anal. Chem. 51:463.

Weinbaum, S.A. and T.T. Muraoka. 1986. Nitrogen redistribution from almond foliage and pericarp to the almond embryo. J. Amer. Soc. Hort. Sci. 111:224-228.

Weinbaum, S.A., K. Uriu, and T.T. Muraoka. 1980. Relationship between $\mathrm{K}^{15} \mathrm{NO}_{3}$ application period and " $\mathrm{N}$ enrichment of apricot blossoms and developing fruit. J. Plant Nutr. 2:699-706.

Weinbaum, S. A., I. Klein, F.E. Broadbent, W.C. Micke, and T.T. Muraoka. 1984. Effects of time of nitrogen application and soil texture on the availability of isotonically labeled fertilizer nitrogen to reproductive and vegetative tissue of mature almond trees. J. Amer. Soc. Hort. Sci. 109:339-343. 